\title{
PATENTS
}

\section{Recent patents in fermentation technology}

\begin{tabular}{|c|c|c|c|c|c|}
\hline Patent \# & Subject & Assignee & Author & $\begin{array}{l}\text { Priority } \\
\text { application } \\
\text { date }\end{array}$ & $\begin{array}{l}\text { Publication } \\
\text { date }\end{array}$ \\
\hline EP 1046706 & $\begin{array}{l}\text { Continuous biocatalytic conversion of an } \\
\text { aqueous solution containing material by } \\
\text { feeding the solution into a bioreactor } \\
\text { containing a biocatalyst and transferring } \\
\text { into a degassing device. }\end{array}$ & $\begin{array}{l}\text { GEA Liquid Processing } \\
\text { Scandinavia } \\
\text { (Skanderborg, Denmark) }\end{array}$ & $\begin{array}{l}\text { Andersen K, } \\
\text { Bergin J, } \\
\text { Lommi HO, } \\
\text { Lynch FJ, } \\
\text { Pajunen EJ, } \\
\text { Viljava TT }\end{array}$ & 4/21/1999 & $10 / 25 / 2000$ \\
\hline US 6133019 & $\begin{array}{l}\text { An apparatus for containing a biocatalyst at a } \\
\text { desired location within a liquid flow path within } \\
\text { a gravitational field; useful in fermentation } \\
\text { processes. }\end{array}$ & $\begin{array}{l}\text { Kinetic Biosystems } \\
\text { (Atlanta, GA) }\end{array}$ & Herman $\mathrm{HH}$ & 12/31/1997 & $10 / 17 / 2000$ \\
\hline DE 19913862 & $\begin{array}{l}\text { Biotransformation of a substrate with poor } \\
\text { solubility in water in a bioreactor containing } \\
\text { an aqueous medium; suitable for the selective } \\
\text { biocatalyzed oxidation of terfenadine to the } \\
\text { corresponding alcohol, which can be converted } \\
\text { into fexofenadine. }\end{array}$ & $\begin{array}{l}\text { Forschungszentrum Jülich } \\
\text { (Jülich, Germany) }\end{array}$ & $\begin{array}{l}\text { Schmitz G, } \\
\text { Takors R, } \\
\text { Wandrey C, } \\
\text { Weuster-Botz D }\end{array}$ & 3/26/1999 & $10 / 5 / 2000$ \\
\hline EP 1041044 & $\begin{array}{l}\text { A process for cleaning wastewater from the } \\
\text { food-processing industry, especially olive oil } \\
\text { production, in which the wastewater has varying } \\
\text { amounts of water and organic substances; } \\
\text { comprises a biological treatment using micro- } \\
\text { organisms, a mechanical process to separate } \\
\text { solids and oils, and selective adsorption } \\
\text { of phenolic components using absorption } \\
\text { resin in an ion-exchange process. }\end{array}$ & $\begin{array}{l}\text { ARGUS } \\
\text { Umweltbiotechnologie } \\
\text { (Berlin) }\end{array}$ & $\begin{array}{l}\text { Liedecke H, } \\
\text { Niebelschuetz H }\end{array}$ & 3/31/1999 & $10 / 4 / 2000$ \\
\hline US 6110713 & $\begin{array}{l}\text { Producing glutamic acid by culturing a } \\
\text { biologically pure culture of ribulose- } \\
\text { monophosphate-pathway-utilizing, } \\
\text { auxotrophic mutant of } \\
\text { Bacillus methanolicus. }\end{array}$ & $\begin{array}{l}\text { Univ. Minnesota } \\
\text { (Minneapolis, MN) }\end{array}$ & $\begin{array}{l}\text { Al-Tahoo N, } \\
\text { Bremmon C, } \\
\text { Flickinger MC, } \\
\text { Hanson RS, } \\
\text { Hur W, } \\
\text { Olson P }\end{array}$ & $3 / 23 / 1993$ & $8 / 29 / 2000$ \\
\hline WO 200041976 & $\begin{array}{l}\text { A bioremediation system for treating palm } \\
\text { oil mill effluent, including a screw press, a } \\
\text { crude oil separator, a sludge separator, and } \\
\text { a bioreactor to convert the sludge liquor to } \\
\text { micro-organic biomass. The method allows } \\
\text { the palm oil mill by-product to enter a complete } \\
\text { food chain with the production of high-value } \\
\text { fish protein as an end product. }\end{array}$ & $\begin{array}{l}\text { Ebara Corp. (Tokyo); } \\
\text { Ebara Eng. Singapore } \\
\text { Pte. Ltd. }\end{array}$ & Mamoru K & 1/14/1999 & $7 / 20 / 2000$ \\
\hline US 6087462 & $\begin{array}{l}\text { Coating compositions comprising polymers } \\
\text { containing zwitterionic monomers bearing a } \\
\text { center of permanent positive charge, for } \\
\text { coating separation membranes (preferably } \\
\text { biofiltration membranes in bioreactors and } \\
\text { fermentation systems. The coating discourages } \\
\text { protein adsorption, rendering the surface suitable } \\
\text { for prolonged contact with living tissues, } \\
\text { body fluids, and protein-containing solutions. }\end{array}$ & $\begin{array}{l}\text { Biocompatibles Ltd. } \\
\text { (Farnham, UK) }\end{array}$ & $\begin{array}{l}\text { Bowers RWJ, } \\
\text { Charles SA, } \\
\text { Jones SA, } \\
\text { Stratford PW }\end{array}$ & $5 / 12 / 1998$ & $7 / 11 / 2000$ \\
\hline WO 200029544 & $\begin{array}{l}\text { A bioreactor for cultivating microorganisms on } \\
\text { solid medium in a contained environment, } \\
\text { comprising stacked modules with communicating } \\
\text { and noncommunicating channels and a mixing } \\
\text { arrangement. The bioreactor combines all of the } \\
\text { operations of microorganism cultivation in a } \\
\text { controlled environment. }\end{array}$ & $\begin{array}{l}\text { Biocon India } \\
\text { (Bangalore, India) }\end{array}$ & $\begin{array}{l}\text { Mazumdar K, } \\
\text { Suryanarayan S }\end{array}$ & 11/17/1998 & $5 / 25 / 2000$ \\
\hline
\end{tabular}

Source: Derwent Information, Alexandria, VA. *The patents in the table are pending. The status of each application is slightly different from country to country. For further details, contact Derwent Information, 1725 Duke St., Suite 250, Alexandria, VA 22314. Tel: 1 (800) DERWENT (info@derwent.com). 